\title{
KRITERIA DESAIN DINDING PENAHAN PADA TANAH CAMPURAN
}

\author{
Dyah Wahyu Apriani ${ }^{1, *}$, Muhammad Hadid ${ }^{1)}$ \\ ${ }^{1)}$ Program Studi Teknik Sipil, Institut Teknologi Kalimantan, Balikpapan \\ ${ }^{*}$ Email: dyahwahyuap@itk.ac.id
}

\begin{abstract}
Retaining wall is one of the reinforcing techniques used to control soil movement. Reinforcement with retaining walls is relatively expensive so an efficient design is needed. Unfortunately, the guidelines for planning a retaining wall are limited. Analysis of design criteria was carried out on silt clay soil taken in the area of the Karang Joang Kalimantan Institute of Technology (ITK) area based on the dimension guide given by Hardiyatmo (2010) and Nakazawa, et al (1980) for safe slope height based on the type of retaining wall. The minimum criteria for cantilever type retaining walls with a slope height of 2-3 meters is the width of the TOE $(A)=$ $B / 3$ meters, the base width retaining wall $(B)=$ minimum of $0.7 \mathrm{H}$ meters, the width of the upper wall $(C)=0.2$ meters and wall thickness $(D)=H / 10-H / 12$ meters, while for slopes with a height of 4- 5 meters the safe dimension range is TOE (A) width $=A / 3$, slope width $(B)$ is designed to be a minimum of $0.9 \mathrm{H}$ meters, width of the wall $(C)=$ minimum 0.2 meters and wall thickness $(D)=H / 10-H / 12$ meters. Gravity retaining wall has design criteria for slopes as high as 2-3 meters of $A=D / 2-D$ meters, $B$ is taken to a minimum of $0.7 \mathrm{H}$ meters, a minimum $C$ value of $0.3 \mathrm{~m}$ and $\mathrm{D}$ of $\mathrm{H} / 8$ - $\mathrm{H} / 6$ meters for slopes with a height of 2-3 meters, meanwhile for slopes with a height of $4-5$ meters, $B$ to a minimum of $0.9 \mathrm{H}$ meters, with a value of $A=D / 2-D$ meters, the $C$ value is designed to be a minimum of 0.3 meters and $\mathrm{D}=\mathrm{H} / \mathrm{8}-\mathrm{H} / 6$ meters.
\end{abstract}

Kata kunci : dinding penahan tanah, gerakan tanah, perkuatan tanah

\section{PENDAHULUAN}

Pemanfaatan lahan untuk pemukiman dan jalan di Kalimantan Timur memiliki tantangan tersendiri akibat dari karakteristik daerah yang berbukit dengan 43,35 \% wilayah daratannya memiliki kemiringan diatas 43,22 \%. Merubah geometri adalah salah satu cara mengatasi permasalahan tersebut, perubahan geometri yang terjadi dapat berupa pemotongan daerah yang berbukit atau penimbunan daerahdaerah cekungan agar layak untuk dikembangkan menjadi fasilitas publik yang aman bagi penggunanya. Penimbunan daerah-daerah cekungan akan menimbulkan urugan tanah dengan ketingian tertentu, hingga pada batas maksimum urugan tersebut akan membentuk lereng yang memiliki kemungkinan untuk longsor.

Stabilitas lereng timbunan sangat penting untuk dianalisis agar meminimalisir pergerakan tanah yang mungkin terjadi di lereng. Gerakan tanah tersebut dapat mengakibatkan kerusakan fasilitas umum, lahan, maupun korban jiwa yang dapat 
melumpuhkan kegiatan pembangunan dan aktivitas ekonomi pada daerah yang mengalami pergerakan tanah, sehingga diperlukan tindakan pengendalian gerakan tanah guna meminimalisir kerugian yang terjadi.

$$
\text { Pengendalian permasalahan }
$$

longsor atau gerakan tanah pada lereng timbunan atau lereng alam adalah dengan mengubah geometri menjadi lebih landai, namun perlu diingat pemotongan lereng berbukit dan pelandaian lereng timbunan perlu memperhatikan kondisi lingkungan dan batas wilayah geometri yang tidak dapat diubah sehingga metode mengubah geometri ini tidak dapat selalu diterapkan. Solusi dari masalah tersebut adalah dengan metode perkuatan.
Dinding penahan tanah adalah salah satu teknik perkuatan yang digunakan untuk menahan tekanan tanah lateral yang ditimbulkan oleh tanah urug atau tanah asli yang labil. Perkuatan dengan dinding penahan tanah relative mahal sehingga diperlukan desain yang efisien. Sayangnya pedoman perencanaan dinding penahan tanah dirasa masih sangat kurang. Hardiyatmo (2010) memberikan estimasi awal dimensi dari beberapa tipe dinding penahan tanah seperti ditunjukkan pada Gambar 1 di bawah yang dapat digunakan sebagai panduan dalam menentukan dimensi dinding penahan tanah. Nakazawa dkk (1980) memberikan pegangan tipe dinding penahan berdasarkan standar ketinggian DPT yang sering digunakan sesuai tabel 1 di bawah.

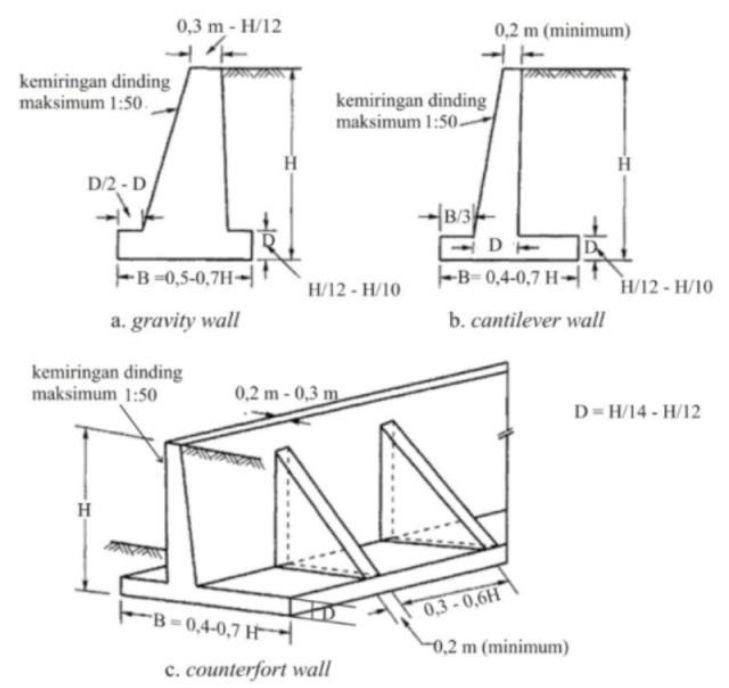

Gambar 1. Estimasi awal dimensi dinding penahan tanah

Timbunan yang ideal dibentuk dari material berupa tanah granular yang homogen sehingga mudah padat tanpa memerlukan upaya pemadatan yang besar dan air dapat terdrainase dengan baik sehingga potensi penambahan berat lereng akibat tanah yang jenuh menjadi kecil dan lereng tetap stabil. Namun pada kenyataan, metode cut and fill yang dilaksanakan pada pembukaan lahan membuat material timbunan tidak terkontrol 
karena berasal dari material yang sama dengan daerah yang akan ditimbun dan properties material timbunan adalah tanah campuran, jarang sekali ditemui material timbunan berupa tanah granular homogen.

Tabel 1. Tinggi pemakaian baku pada berbagai dinding penahan

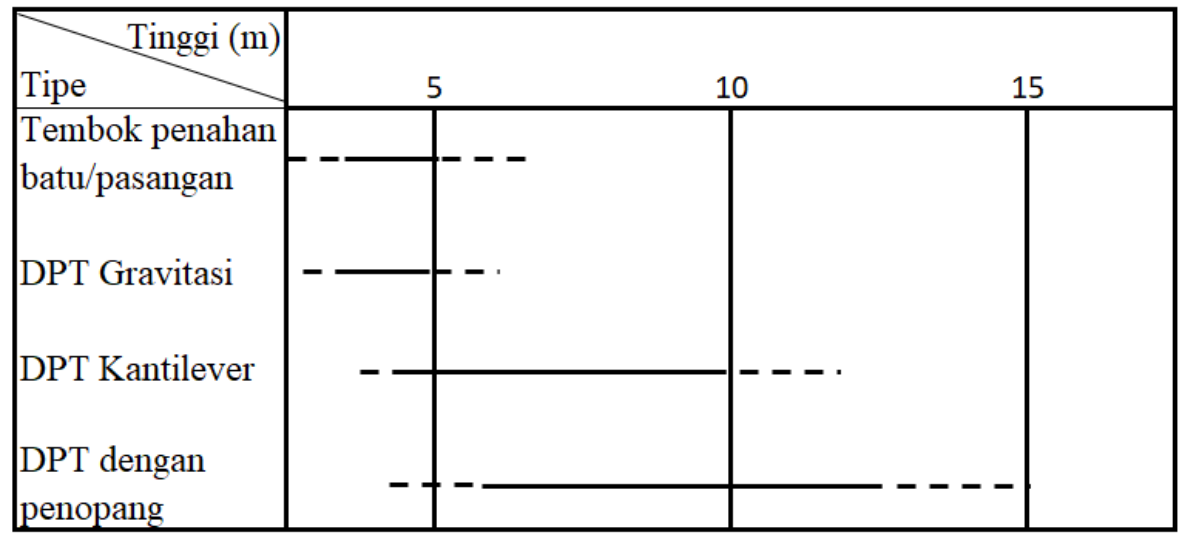

Penggunaan panduan yang diberikan Hardiyatmo (2010) dan Nakazawa dkk (1980) belum memberikan pemahaman yang cukup dalam pelaksanaan pembangunan DPT di lapangan, dikarenakan parameter tanah disetiap tempat berbeda-beda dan akan berpengaruh pada dimensi yang dipakai serta stabilitas dari dinding penahan yang dibangun.

Penelitian ini akan menghasilkan pedoman perancangan dinding penahan dengan material urugan berupa tanah campuran sesuai kondisi lapangan, selain itu penelitian ini juga akan menguji dimensi yang diberikan oleh Hardiyatmo (2010) dan ketinggian lereng yang diberikan Nakazawa dkk (1980) dengan mengambil contoh kasus sesuai data yang diambil di wilayah Institut Teknologi Kalimantan (ITK). serta memberikan alternatif bentuk dinding penahan yang beragam namun tetap mudah dalam perolehan material dan pelaksanaan. Tipe dinding penahan tanah yang akan dianalisis adalah tipe kantilever dan gravitasi.

Metode coba-coba dilakukan untuk menentukan dimensi dinding penahan tanah yang tepat berdasarkan panduan dimensi yang diberikan Hardiyatmo (2010) serta memperhitungkan variasi ketinggian lereng timbunan dengan panduan ketinggian lereng yang diberikan Nakazawa dkk (1980). Analisis stabilitas dilakukan terhadap kemungkinan geser, guling dan kapasitas dukung tanah sehingga diperoleh desain dinding penahan yang paling efektif dan aman. Sebagai hasil akhir diharapkan penelitian ini dapat dijadikan sebagai salah satu pedoman singkat dan sederhana dalam perancangan dinding penahan tanah di wilayah kampus Institut Teknologi Kalimantan (ITK) ataupun acuan dalam perancangan dinding penahan tanah dengan material urugan berupa tanah campuran. 


\section{METODE PENELITIAN}

Penelitian ini adalah penelitian pemodelan dengan menggunakan rumus empiris. output dari penelitian ini adalah rentang dimensi dinding penahan tanah yang aman dengan ketinggian lereng yang divariasikan.

\section{Data Penelitian}

Data penelitian yang dipakai diambil dari dua lokasi di wilayah Kampus
Institut Teknologi Kalimantan (ITK) Karang Joang yakni Rusunawa dan Gedung Perkuliahan EFG sesuai Gambar 2 dimana berdasarkan hasil penyidikan tipe tanahnya berupa lempung kelanauan atau campuran karena memiliki parameter kohesi (c) dan sudut gesek dalam $(\varphi)$. Propertis tanah yang digunakan dalam analisis sesuai Tabel 2.

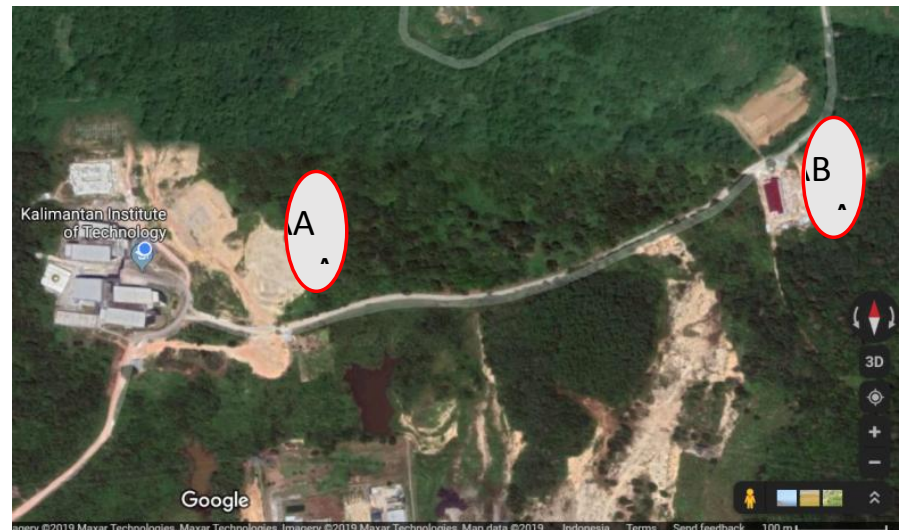

Gambar 2. Letak pengambilan data tanah untuk pengujian (A)

Gedung EFG dan (B) Rusunawa (Skala 1: 700)

Tabel 2. Data properties tanah

\begin{tabular}{lccc}
\hline \multicolumn{1}{c}{ Lokasi } & Kohesi $(\mathrm{c})\left(\mathrm{kN} / \mathrm{m}^{2}\right)$ & Sudut Gesek dalam $(\varphi)\left(^{\circ}\right)$ & $\begin{array}{c}\text { Berat vol. tanah }(\gamma) \\
\left(\mathrm{kN} / \mathrm{m}^{3}\right)\end{array}$ \\
\hline Rusunawa & 29,62 & 20,97 & 16,67 \\
Gedung EFG & 29,6 & 17,62 & 16,67 \\
\hline
\end{tabular}

\section{Analisis Kriteria Desain}

Penentuan kriteria desain dinding penahan dilakukan dengan cara cobacoba terhadap dimensi berdasarkan panduan yang diberikan oleh Hardiyatmo (2010), dimana dimensi yang akan divariasikan dapat dilihat pada Tabel 3 dengan penjelasan mengenai parameter-parameternya dapat dilihat pada Gambar 3. Tipe dinding yang ditinjau adalah dinding penahan tipe gravitasi dan kantiliver dengan pertimbangan kemudahan pelaksanaan dan material. Ketinggian lereng ditinjau sesuai saran Nakazawa dkk (1980) dimana tipe gravitasi aman untuk lereng dengan ketinggian sampai $5 \mathrm{~m}$ dan kantilever aman sampai $10 \mathrm{~m}$ namun ketinggian lereng pada penelitian ini dibatasi pada rentang 25 meter sesuai kondisi di wilayah tinjauan yakni Kampus ITK Karang Joang. 
Pada analisis nilai B dan D akan di variasikan sesuai rentang pada Tabel 3 , nilai $\mathrm{C}$ didesain pada batas minimal sesuai yang diberikan oleh Hardiyatmo (2010) sedangkan nilai A pada DPT tipe kantilever diambil sebesar B/3 dan DPT tipe gravitsi akan divariasikan pada rentang D/2-D. H pada Tabel 3 merupakan ketinggian lereng dalam meter. Seluruh kombinasi dibuat sesuai rentang dimensi yang diberikan oleh Hardiyatmo (2010) sehingga diperoleh dimensi yang optimal dan aman.

Tabel 3. Trial dimensi

\begin{tabular}{ccccc}
\hline Tipe & $\mathrm{B}(\mathrm{m})$ & $\mathrm{D}(\mathrm{m})$ & $\mathrm{C}(\mathrm{m})$ & $\mathrm{A}(\mathrm{m})$ \\
\hline Kantilever & $(0.4-0.7) \mathrm{H}$ & $\mathrm{H} / 12-\mathrm{H} / 10$ & 0.2 & $\mathrm{~B} / 3$ \\
Gravitasi & $(0.5-0.7) \mathrm{H}$ & $\mathrm{H} / 8-\mathrm{H} / 6$ & 0.3 & $\mathrm{D} / 2-\mathrm{D}$ \\
\hline
\end{tabular}
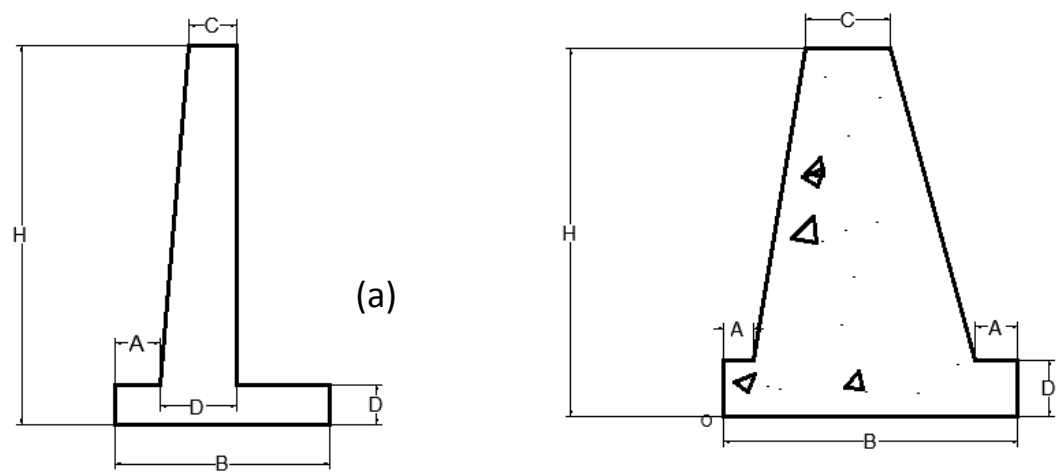

(b)

Gambar 3. Parameter dimensi dinding Penahan Tanah (a) Kantilever, (b) Gravitasi

\section{Analisis Stabilitas Dinding Penahan}

\section{Tanah}

Dimensi dinding penahan tanah yang dihasilkan dari analisis kriteria desain harus dianalisis keamanannya berdasarkan tinjauan guling, geser dan kapasitas dukung tanah. Menurut Bowles (1997) besar angka keamanan untuk tanah kohesif minimum 2 untuk tinjauan geser dan guling dan minimum 3 untuk kapasitas dukung tanah. Analisis keamanan untuk kapasitas dukung tanah dilakukan dengan Persamaan Error! Reference source not found. yang diberikan oleh Hansen (1961) dengan pertimbangan bahwa dinding penahan tidak hanya menerima beban vertical dan horisontal yang jatuh dipusat berat dinding penahan, tetapi juga menerima beban dengan sudut tertentu yang bekerja eksentris. Faktor kemiringan beban diperoleh berdasarkan Tabel 4 . Nilai sudut gesek dalam yang ada maka diperoleh faktor kapasitas dukung Hansen (196) seperti Tabel 5 di bawah.

$q_{u}=d_{c} i_{c} c N_{c}+d_{q} i_{q} D_{f} \gamma N_{q}+d_{\gamma} i_{\gamma} 0,5 B \gamma N_{\gamma}$

dengan : 


$$
\begin{array}{ll}
d_{c}, d_{q}, d_{\gamma} & =\text { faktor kedalaman (Hansen, 1970) diambil }=1 \\
i_{c}, i_{q}, i_{\gamma} & =\text { faktor kemiringan beban (Hansen, 1970) } \\
\mathrm{B} & =\text { lebar dasar pondasi sebenarnya }(\mathrm{m}) \\
\mathrm{e} & =\text { eksentrisitas beban }(\mathrm{m}) \\
\mathrm{\gamma} & =\text { berat volume tanah }\left(\mathrm{kN} / \mathrm{m}^{3}\right) \\
N_{c}, N_{q}, N_{\gamma} & =\text { faktor-faktor kapasitas dukung }
\end{array}
$$

Tabel 4. Faktor kemiringan beban Hansen (1961)

\begin{tabular}{ccc}
\hline Faktor kemiringan beban & Nilai & Keterangan \\
\hline $\mathrm{i}_{\mathrm{c}}$ & $i_{q}-\frac{\left(1-i_{q}\right)}{N_{q}-1}$ & \\
$\mathrm{i}_{\mathrm{q}}$ & {$\left[1-\frac{0,5 H}{V+A^{\prime} c_{a} \operatorname{ctg} \varphi}\right]^{5} \geq 0$} & \\
$\mathrm{i}_{\mathrm{v}}$ & {$\left[1-\frac{0,7 H}{V+A^{\prime} c_{a} \operatorname{ctg} \varphi}\right]^{5} \geq 0$} & untuk dasar horisontal \\
\hline
\end{tabular}

Tabel 5. Faktor kapasitas dukung Hansen (1961)

\begin{tabular}{lcccc}
\hline Lokasi & $\begin{array}{c}\text { Sudut Gesek } \\
\text { dalam }(\varphi)\left({ }^{\circ}\right)\end{array}$ & $\mathrm{Nc}$ & $\mathrm{Nq}$ & $\mathrm{N \gamma}$ \\
\hline Rusunawa & 20,97 & 15.7806 & 7.0499 & 3.4835 \\
Gedung EFG & 17,62 & 12.80816 & 5.07184 & 1.9456 \\
\hline
\end{tabular}

\section{HASIL DAN PEMBAHASAN}

Percobaan dimensi untuk DPT tipe Kantilever dengan data lokasi Rusunawa diperoleh kombinasi dimensi yang aman sesuai dengan Tabel 6. Dari Tabel 6 dapat dibuat rentang dimensi minimum yang aman untuk DPT tipe Kantilever dengan data yang diambil di Rusunawa berdasarkan ketinggian lereng sesuai Tabel 7 . Dimensi yang aman untuk DPT tipe kantilever berdasarkan data Gedung EFG dapat dilihat pada Tabel 8.

Berdasarkan hasil analisis rentang dimensi yang diberikan oleh Hardiyatmo (2010) hanya aman pada lereng dengan ketinggian 2-3 meter sehingga untuk lereng dengan ketinggian 4-5 meter dilakukan perbesaran dimensi B untuk memperoleh angka aman sesuai syarat yang ada. Rentang dimensi minimum untuk DPT tipe kantilever berdasarkan data yang diambil pada Gedung EFG dapat dilihat pada Tabel 9.

Dari dua kombinasi dimensi yang diperoleh maka dapat dibuat kombinasi dimensi minimum yang aman untuk tipe tanah lempung kelanauan sesuai dengan jenis tanah yang diambil pada lokasi Rusunawa dan Gedung EFG sesuai Tabel 10. Pemilihan kriteria desain DPT tipe kantilever pada tanah campuran didasarkan pada dimensi minimum yang masih aman berdasarkan ketinggian lereng yang ditinjau.

Analisis terhadap dinding penahan tanah tipe gravitasi berdasarkan data yang diambil di lokasi Rusunawa dapat dilihat pada Tabel 11 yang juga memperlihatkan dimensi yang aman untuk ketinggian lereng 2-5 meter. Berdasarkan data 
pada Tabel 11 dapat dibuat rentang dimensi minimum yang aman untuk DPT tipe gravitasi dengan data yang diambil di Rusunawa berdasarkan ketinggian lereng sesuai Tabel 12 Dimensi yang aman untuk DPT tipe kantilever berdasarkan data Gedung EFG dapat dilihat pada Tabel 13.

Tabel 6. Kombinasi dimensi aman DPT Kantilever di Rusunawa

\begin{tabular}{cccccccccccc}
\hline No & $\mathrm{H}$ & $\mathrm{A}(\mathrm{m})$ & $\mathrm{B}(\mathrm{m})$ & $\mathrm{C}(\mathrm{m})$ & $\mathrm{D}(\mathrm{m})$ & $\mathrm{c}(\mathrm{kN} / \mathrm{m} 3)$ & $\boldsymbol{\omega}\left(^{\circ}\right)$ & Geser & Guling & Tanah & $\mathrm{ket}$ \\
\hline 1 & 2 & $\mathrm{~B} / 3$ & $0.6 \mathrm{H}$ & 0.2 & $\mathrm{H} / 10$ & & & 3.06 & 2.31 & 7.43 & $\mathrm{Ok}$ \\
2 & 3 & $\mathrm{~B} / 3$ & $0.6 \mathrm{H}$ & 0.2 & $\mathrm{H} / 10$ & & & 2.27 & 2.25 & 4.43 & $\mathrm{Ok}$ \\
3 & 4 & $\mathrm{~B} / 3$ & $0.7 \mathrm{H}$ & 0.2 & $\mathrm{H} / 10$ & & & 2.18 & 3.01 & 4.67 & $\mathrm{Ok}$ \\
4 & 5 & $\mathrm{~B} / 3$ & $0.8 \mathrm{H}$ & 0.2 & $\mathrm{H} / 10$ & 29.62 & 20.97 & 2.18 & 3.89 & 4.74 & $\mathrm{Ok}$ \\
5 & 2 & $\mathrm{~B} / 3$ & $0.6 \mathrm{H}$ & 0.2 & $\mathrm{H} / 12$ & & & 3.05 & 2.29 & 7.39 & $\mathrm{Ok}$ \\
6 & 3 & $\mathrm{~B} / 3$ & $0.6 \mathrm{H}$ & 0.2 & $\mathrm{H} / 12$ & & & 2.26 & 2.23 & 4.41 & $\mathrm{Ok}$ \\
7 & 4 & $\mathrm{~B} / 3$ & $0.7 \mathrm{H}$ & 0.2 & $\mathrm{H} / 12$ & & & 2.17 & 2.98 & 4.70 & $\mathrm{Ok}$ \\
8 & 5 & $\mathrm{~B} / 3$ & $0.8 \mathrm{H}$ & 0.2 & $\mathrm{H} / 12$ & & & 2.17 & 3.86 & 4.79 & $\mathrm{Ok}$ \\
\hline
\end{tabular}

Tabel 7. Dimensi minimum DPT kantilever di Rusunawa

\begin{tabular}{ccccc}
\hline $\mathrm{H}(\mathrm{m})$ & $\mathrm{A}(\mathrm{m})$ & $\mathrm{B}(\mathrm{m})$ & $\mathrm{C}(\mathrm{m})$ & $\mathrm{D}(\mathrm{m})$ \\
\hline $2-3$ & $\mathrm{~B} / 3$ & $\min 0.6 \mathrm{H}$ & 0.2 & $\mathrm{H} / 10-\mathrm{H} / 12$ \\
4 & $\mathrm{~B} / 3$ & $\min 0.7 \mathrm{H}$ & 0.2 & $\mathrm{H} / 10-\mathrm{H} / 12$ \\
5 & $\mathrm{~B} / 3$ & $\min 0.8 \mathrm{H}$ & 0.2 & $\mathrm{H} / 10-\mathrm{H} / 12$ \\
\hline
\end{tabular}

Tabel 8. Kombinasi dimensi aman DPT Kantilever di Gedung EFG

\begin{tabular}{|c|c|c|c|c|c|c|c|c|c|c|c|}
\hline No & $\mathrm{H}$ & $\mathrm{A}(\mathrm{m})$ & $\mathrm{B}(\mathrm{m})$ & $\mathrm{C}(\mathrm{m})$ & $\mathrm{D}(\mathrm{m})$ & $\mathrm{c}(\mathrm{kN} / \mathrm{m} 3)$ & $\omega\left({ }^{\circ}\right)$ & Geser & Guling & Tanah & ket \\
\hline 1 & 2 & $\mathrm{~B} / 3$ & $0.7 \mathrm{H}$ & 0.2 & $\mathrm{H} / 10$ & \multirow{8}{*}{29.60} & \multirow{8}{*}{17.62} & 3.00 & 2.75 & 7.44 & Ok \\
\hline 2 & 3 & $\mathrm{~B} / 3$ & $0.7 \mathrm{H}$ & 0.2 & $\mathrm{H} / 10$ & & & 2.20 & 2.69 & 4.50 & Ok \\
\hline 3 & 4 & $\mathrm{~B} / 3$ & $0.8 \mathrm{H}$ & 0.2 & $\mathrm{H} / 10$ & & & 2.05 & 3.46 & 4.20 & Ok \\
\hline 4 & 5 & $\mathrm{~B} / 3$ & $0.9 \mathrm{H}$ & 0.2 & $\mathrm{H} / 10$ & & & 2.00 & 4.34 & 3.97 & Ok \\
\hline 5 & 2 & $\mathrm{~B} / 3$ & $0.7 \mathrm{H}$ & 0.2 & $\mathrm{H} / 12$ & & & 2.99 & 2.73 & 7.45 & Ok \\
\hline 6 & 3 & $\mathrm{~B} / 3$ & $0.7 \mathrm{H}$ & 0.2 & $\mathrm{H} / 12$ & & & 2.19 & 2.67 & 4.52 & Ok \\
\hline 7 & 4 & $\mathrm{~B} / 3$ & $0.8 \mathrm{H}$ & 0.2 & $\mathrm{H} / 12$ & & & 2.04 & 3.43 & 4.24 & Ok \\
\hline 8 & 5 & $\mathrm{~B} / 3$ & $0.9 \mathrm{H}$ & 0.2 & $\mathrm{H} / 12$ & & & 2.00 & 4.34 & 3.97 & Ok \\
\hline
\end{tabular}

Tabel 9. Kombinasi minimum kantiliver di Gedung EFG

\begin{tabular}{ccccc}
\hline $\mathrm{H}(\mathrm{m})$ & $\mathrm{A}(\mathrm{m})$ & $\mathrm{B}(\mathrm{m})$ & $\mathrm{C}(\mathrm{m})$ & $\mathrm{D}(\mathrm{m})$ \\
\hline $2-3$ & $\mathrm{~B} / 3$ & $\min 0.7$ & 0.2 & $\mathrm{H} / 10-\mathrm{H} / 12$ \\
4 & $\mathrm{~B} / 3$ & $\min 0.8$ & 0.2 & $\mathrm{H} / 10-\mathrm{H} / 12$ \\
5 & $\mathrm{~B} / 3$ & $\min 0.9$ & 0.2 & $\mathrm{H} / 10-\mathrm{H} / 12$ \\
\hline
\end{tabular}

Tabel 10. Kriteria desain DPT Kantilever pada tanah campuran

\begin{tabular}{ccccc}
\hline $\mathrm{H}(\mathrm{m})$ & $\mathrm{A}(\mathrm{m})$ & $\mathrm{B}(\mathrm{m})$ & $\mathrm{C}(\mathrm{m})$ & $\mathrm{D}(\mathrm{m})$ \\
\hline $2-3$ & $\mathrm{~B} / 3$ & $\min 0.7 \mathrm{H}$ & 0.2 & $\mathrm{H} / 10-\mathrm{H} / 12$ \\
$4-5$ & $\mathrm{~B} / 3$ & $\min 0.9 \mathrm{H}$ & 0.2 & $\mathrm{H} / 10-\mathrm{H} / 12$ \\
\hline
\end{tabular}


Tabel 11. Kombinasi dimensi aman DPT Gravitasi di Rusunawa

\begin{tabular}{cccccccccccc}
\hline No & $\mathrm{H}(\mathrm{m})$ & $\mathrm{B}(\mathrm{m})$ & $\mathrm{D}(\mathrm{m})$ & $\mathrm{C}(\mathrm{m})$ & $\mathrm{A}(\mathrm{m})$ & $\mathrm{c}(\mathrm{kN} / \mathrm{m} 3)$ & $\varphi\left(^{\circ}\right)$ & Geser & Guling & Tanah & Ket \\
\hline 1 & 2 & $0.6 \mathrm{H}$ & $\mathrm{H} / 8$ & 0.3 & $\mathrm{D} / 2$ & & & 3.20 & 2.58 & 9.48 & Ok \\
2 & 3 & $0.6 \mathrm{H}$ & $\mathrm{H} / 8$ & 0.3 & $\mathrm{D} / 2$ & & & 2.42 & 2.53 & 6.89 & Ok \\
3 & 4 & $0.6 \mathrm{H}$ & $\mathrm{H} / 8$ & 0.3 & $\mathrm{D} / 2$ & & & 2.03 & 2.50 & 5.47 & Ok \\
4 & 5 & $0.7 \mathrm{H}$ & $\mathrm{H} / 8$ & 0.3 & $\mathrm{D} / 2$ & & & 2.10 & 3.39 & 5.63 & Ok \\
5 & 2 & $0.6 \mathrm{H}$ & $\mathrm{H} / 6$ & 0.3 & $\mathrm{D}$ & & & 3.10 & 2.41 & 10.45 & Ok \\
6 & 3 & $0.6 \mathrm{H}$ & $\mathrm{H} / 6$ & 0.3 & $\mathrm{D}$ & 29.62 & 20.97 & 2.32 & 2.36 & 7.60 & Ok \\
7 & 5 & $0.7 \mathrm{H}$ & $\mathrm{H} / 6$ & 0.3 & $\mathrm{D}$ & & & 2.01 & 3.20 & 6.24 & Ok \\
8 & 2 & $0.6 \mathrm{H}$ & $\mathrm{H} / 6$ & 0.3 & $\mathrm{D} / 2$ & & & 3.20 & 2.57 & 9.53 & Ok \\
9 & 3 & $0.6 \mathrm{H}$ & $\mathrm{H} / 6$ & 0.3 & $\mathrm{D} / 2$ & & & 2.42 & 2.52 & 6.92 & Ok \\
10 & 4 & $0.6 \mathrm{H}$ & $\mathrm{H} / 6$ & 0.3 & $\mathrm{D} / 2$ & & & 2.03 & 2.49 & 5.49 & Ok \\
11 & 5 & $0.7 \mathrm{H}$ & $\mathrm{H} / 6$ & 0.3 & $\mathrm{D} / 2$ & & & 2.10 & 3.39 & 5.63 & Ok \\
\hline
\end{tabular}

Tabel 12. Dimensi minimum DPT gravitasi di Rusunawa

\begin{tabular}{ccccc}
\hline $\mathrm{H}(\mathrm{m})$ & $\mathrm{B}(\mathrm{m})$ & $\mathrm{D}(\mathrm{m})$ & $\mathrm{C}(\mathrm{m})$ & $\mathrm{A}(\mathrm{m})$ \\
\hline $2-4$ & $\min 0.6 \mathrm{H}$ & $\mathrm{H} / 6-\mathrm{H} / 8$ & 0.3 & $\mathrm{D} / 2$ \\
5 & $\min 0.7 \mathrm{H}$ & $\mathrm{H} / 6-\mathrm{H} / 8$ & 0.3 & $\mathrm{D} / 2$ \\
\hline
\end{tabular}

Tabel 13. Kombinasi dimensi aman DPT Gravitasi di lokasi Gedung EFG

\begin{tabular}{|c|c|c|c|c|c|c|c|c|c|c|c|}
\hline No & $\begin{array}{c}\mathrm{H} \\
(\mathrm{m})\end{array}$ & $\begin{array}{c}\mathrm{B} \\
(\mathrm{m})\end{array}$ & $\begin{array}{c}\mathrm{D} \\
(\mathrm{m})\end{array}$ & $\begin{array}{c}\mathrm{C} \\
(\mathrm{m})\end{array}$ & $\mathrm{A}(\mathrm{m})$ & $\begin{array}{c}\mathrm{c} \\
(\mathrm{kN} / \mathrm{m} 3)\end{array}$ & $\omega\left(^{\circ}\right)$ & Geser & Guling & Tanah & ket \\
\hline 1 & 2 & $0.7 \mathrm{H}$ & $\mathrm{H} / 8$ & 0.3 & $\mathrm{D} / 2$ & \multirow{16}{*}{29.60} & \multirow{16}{*}{17.62} & 3.13 & 3.10 & 8.54 & $\mathrm{Ok}$ \\
\hline 2 & 3 & $0.7 \mathrm{H}$ & $\mathrm{H} / 8$ & 0.3 & $\mathrm{D} / 2$ & & & 2.34 & 3.04 & 6.18 & Ok \\
\hline 3 & 4 & $0.8 \mathrm{H}$ & $\mathrm{H} / 8$ & 0.3 & $\mathrm{D} / 2$ & & & 2.22 & 3.94 & 5.60 & Ok \\
\hline 4 & 5 & $0.9 \mathrm{H}$ & $\mathrm{H} / 8$ & 0.3 & $\mathrm{D} / 2$ & & & 2.19 & 4.97 & 5.16 & Ok \\
\hline 5 & 2 & $0.7 \mathrm{H}$ & $\mathrm{H} / 8$ & 0.3 & D & & & 3.08 & 2.98 & 9.19 & Ok \\
\hline 6 & 3 & $0.7 \mathrm{H}$ & $\mathrm{H} / 8$ & 0.3 & D & & & 2.28 & 2.92 & 6.66 & $\mathrm{Ok}$ \\
\hline 7 & 4 & $0.8 \mathrm{H}$ & $\mathrm{H} / 8$ & 0.3 & $\mathrm{D}$ & & & 2.16 & 3.81 & 6.04 & Ok \\
\hline 8 & 5 & $0.9 \mathrm{H}$ & $\mathrm{H} / 8$ & 0.3 & D & & & 2.14 & 4.82 & 5.54 & Ok \\
\hline 9 & 2 & $0.7 \mathrm{H}$ & $\mathrm{H} / 6$ & 0.3 & D & & & 3.06 & 2.93 & 9.37 & Ok \\
\hline 10 & 3 & $0.7 \mathrm{H}$ & $\mathrm{H} / 6$ & 0.3 & D & & & 2.27 & 2.87 & 6.78 & Ok \\
\hline 11 & 4 & $0.8 \mathrm{H}$ & $\mathrm{H} / 6$ & 0.3 & D & & & 2.15 & 3.76 & 4.48 & Ok \\
\hline 12 & 5 & $0.9 \mathrm{H}$ & $\mathrm{H} / 6$ & 0.3 & $\mathrm{D}$ & & & 2.13 & 4.78 & 5.60 & Ok \\
\hline 13 & 2 & $0.7 \mathrm{H}$ & $\mathrm{H} / 6$ & 0.3 & $\mathrm{D} / 2$ & & & 3.13 & 3.09 & 8.56 & Ok \\
\hline 14 & 3 & $0.7 \mathrm{H}$ & $\mathrm{H} / 6$ & 0.3 & $\mathrm{D} / 2$ & & & 2.33 & 3.03 & 6.18 & Ok \\
\hline 15 & 4 & $0.8 \mathrm{H}$ & $\mathrm{H} / 6$ & 0.3 & $\mathrm{D} / 2$ & & & 2.22 & 3.94 & 5.59 & Ok \\
\hline 16 & 5 & $0.9 \mathrm{H}$ & $\mathrm{H} / 6$ & 0.3 & $\mathrm{D} / 2$ & & & 2.20 & 4.97 & 5.13 & Ok \\
\hline
\end{tabular}

Rentang dimensi minimum yang aman untuk DPT tipe gravitasi dengan data yang diambil di Gedung EFG berdasarkan ketinggian lereng dapat dilihat pada Tabel 14. Dari dua kombinasi dimensi yang diperoleh 
maka dapat dibuat kombinasi dimensi minimum yang aman untuk tipe tanah lempung kelanauan sesuai dengan jenis tanah yang diambil pada lokasi Rusunawa dan Gedung EFG sesuai Tabel 15. Pemilihan kriteria desain DPT tipe kantilever pada tanah campuran didasarkan pada dimensi minimum yang masih aman berdasarkan ketinggian lereng yang ditinjau.

Hasil analisis kriteria desain menunjukkan dimensi yang diberikan Hardiyatmo (2010) tidak dapat langsung digunakan untuk perancangan di lapangan, melainkan perlu adanya analisis kekuatan tanah yang didasarkan pada data tanah yang ada di lapangan. Hal tersebut terlihat untuk lereng dengan ketinggian 4-5 meter terdapat rentang nilai yang tidak disebutkan oleh Hardiyatmo (2010) dengan DPT (B) maksimal sebesar 0.7 $\mathrm{H}$ namun harus diperbesar sampai 0.8 0.9 H. Selain itu ketinggian lereng yang dapat di tahan berdasarkan tipe DPT yang diberikan Nakazawa dkk (1980) juga perlu dilakukan analisis kembali terkait properties tanah yang ada, karena berdasarkan analisis DPT kantiliver hanya dapat menahan lereng setinggi maksimal 3 meter dengan panduan dimensi yang diberikan oleh Hardiyatmo (2010) dan menahan lereng maksimal 5 meter jika nilai lebar dasar DPT (B) diperbesar menjadi $0.9 \mathrm{H}$ meter.

Tabel 14. Dimensi minimum DPT gravitasi di Gedung EFG

\begin{tabular}{ccccc}
\hline $\mathrm{H}(\mathrm{m})$ & $\mathrm{B}(\mathrm{m})$ & $\mathrm{D}(\mathrm{m})$ & $\mathrm{C}(\mathrm{m})$ & $\mathrm{A}(\mathrm{m})$ \\
\hline $2-3$ & $\min 0.7 \mathrm{H}$ & $\mathrm{H} / 8-\mathrm{H} / 6$ & 0.3 & $\mathrm{D} / 2-\mathrm{D}$ \\
4 & $\min 0.8 \mathrm{H}$ & $\mathrm{H} / 8-\mathrm{H} / 6$ & 0.3 & $\mathrm{D} / 2-\mathrm{D}$ \\
5 & $\min 0.9 \mathrm{H}$ & $\mathrm{H} / 8-\mathrm{H} / 6$ & 0.3 & $\mathrm{D} / 2-\mathrm{D}$ \\
\hline
\end{tabular}

Tabel 15. Kriteria Desain DPT Gravitasi pada tanah campuran

\begin{tabular}{ccccc}
\hline $\mathrm{H}(\mathrm{m})$ & $\mathrm{B}(\mathrm{m})$ & $\mathrm{D}(\mathrm{m})$ & $\mathrm{C}(\mathrm{m})$ & $\mathrm{A}(\mathrm{m})$ \\
$2-3$ & $\min 0.7 \mathrm{H}$ & $\mathrm{H} / 8-\mathrm{H} / 6$ & 0.3 & $\mathrm{D} / 2-\mathrm{D}$ \\
$4-5$ & $\min 0.9 \mathrm{H}$ & $\mathrm{H} / 8-\mathrm{H} / 6$ & 0.3 & $\mathrm{D} / 2-\mathrm{D}$ \\
\hline
\end{tabular}

\section{SIMPULAN}

Rentang dimensi dinding penahan tanah yang aman untuk tanah dengan tipe lempung kelanauan di wilayah kampus ITK Karang Joang Untuk tipe kantilever rentang dimensi yang aman adalah lebar $\operatorname{TOE}(\mathrm{A})=\mathrm{B} / 3$ meter, lebar kaki dinding penahan tanah $(\mathrm{B})=$ minimum $0,7 \mathrm{H}$ meter, lebar atas dinding penahan tanah $(\mathrm{C})=0,2$ meter dan tebal dinding penahan $(D)=H / 10$ -
H/12 meter untuk lereng dengan ketinggian 2-4 meter, sementara untuk lereng dengan ketinggian 5 meter rentang dimensi yang aman adalah nilai $\mathrm{A}=\mathrm{B} / 3, \mathrm{~B}$ didesain minimum 0.9 $\mathrm{H}$ meter, $\mathrm{C}=$ minimum 0,2 meter dan $\mathrm{D}=\mathrm{H} / 10-\mathrm{H} / 12$ meter. Untuk DPT tipe gravitasi adalah sebesar $\mathrm{A}=\mathrm{D} / 2-\mathrm{D}$ meter, $\mathrm{B}$ diambil minimum $0,7 \mathrm{H}$ meter, nilai $\mathrm{C}$ minimum $0,3 \mathrm{~m}$ dan $\mathrm{D}$ sebesar $\mathrm{H} / 8$ - H/6 meter untuk lereng 
dengan ketinggian 2-3 meter., Kampus ITK Karang Joang, untuk itu sementara itu untuk lereng dengan penulis mengucapkan terimakasih ketinggian 4-5 meter, dimensi yang kepada tim tersebut.

diberikan oleh Hardiyatmo (2010) tidak aman sehingga harus diperbesar pada bagian $\mathrm{B}$ menjadi minimum $0,9 \mathrm{H}$ meter, dengan nilai $\mathrm{A}=\mathrm{D} / 2-\mathrm{D}$ meter, nilai $\mathrm{C}$ dirancang minimum sebesar 0,3 meter dan $\mathrm{D}=\mathrm{H} / 8-\mathrm{H} / 6$ meter. Dari hasil penelitian memperlihatkan bahwa panduan yang diberikan Hardiyatmo (2010) tentang rentang dimensi DPT tidak dapat langsung diterapkan pada pembangunan DPT di lapangan, melainkan harus dianalisis terhadap parameter tanah yang bekerja pada DPT serta analisis stabilitasnya.

\section{UCAPAN TERIMA KASIH}

Penelitian ini terlaksana berkat dukungan ketersediaan data dari tim sarana dan prasarana Pembangunan

\section{DAFTAR PUSTAKA}

Bowles, J. E., 1997, Foundation Analysis and Design, $5^{\text {th }}$ Edition, Washinton D.C., Library of Congress Cataloging-inPublication Data

Hansen, J. B., 1961, Earth Pressure calculation, Copenhagen, Denmark, Danish Technical Press,

Hardiyatmo, H.C., 2010, Analisis dan Perancangan Fondasi I, $1^{\text {th }}$ Edition. Yogyakarta, Gadjah Mada University Press

Nakazawa, Kazuto dkk., 1980, Mekanika Tanah dan Teknik Fondasi, Jakarta, PT Pradya Paramita 